\title{
Acid-Base Indicator Properties of Dye from Local Plant: The Rosella Calyces (Hibiscus Sabdariffa)
}

\author{
Onuegbu Genevieve, Nnorom Onyekachi, Okonkwo Samuel Nonso* and Ojiaku Pascal \\ Department of Polymer and Textile Engineering, Federal University of Technology Owerri, Imo State, Nigeria
}

\begin{abstract}
The dye from the Calyces Hibiscus Sabdariffa (Zobo) was extracted and used as acid-base indicator for the standardization of acid and determination of the molar masses of some selected acids. The Calyces Hibiscus sabdariffa was peeled, washed and heated in an oven at $60^{\circ} \mathrm{C}$. It was ground into powder and soaked in hot and cold ethano for the extraction. Part of the extract was filtered and concentrated by subjecting the extract to slow heating which yielded $1.5 \mathrm{~kg}$ of the Hibiscus sabdariffa indicator. Hot and cold extracts of the Hibiscus sabdariffa were used for the standardization of acid with $0.03 \mathrm{M}$ concentration of the bases. On the preliminary test carried out on basic medium, the calyces Hibiscus sabdariffa indicator turned red in acidic condition and green in basic medium, both hot and cold indicators yielded sharp and intense colours at the end points during titration processes. However, there were no colour changes for weak acid versus weak bases $\left(\mathrm{H}_{2} \mathrm{C}_{2} \mathrm{O}_{4} / \mathrm{Na}_{2} \mathrm{CO}_{3}\right.$ and $\left.\mathrm{H}_{2} \mathrm{C}_{2} \mathrm{O}_{4} / \mathrm{B}_{4} \mathrm{Na}_{2} \mathrm{O}_{7}\right)$. The mean volumes of the acids used were determined and used for the determination of the molar concentration and mass concentration of all the acids used in the research work.
\end{abstract}

Keywords: Indicator $\cdot$ Acids $•$ Bases $\cdot$ Hibiscus sabdariffa $\bullet$ Rosella Calyces $・$ Dye

\section{Introduction}

Extensive studies have been made on the use of natural products which are readily available, easily prepared, eco-friendly, less hazardous and of low cost, as indicators in acid-base titrations. These products can serve as substitutes for the synthetic compounds which are costly and harmful. These natural products can be obtained from various parts of plants like leaves, roots, fruits and stems. Example of such plant is Hibiscus sabdariffa known as "Roselle" (Zobo), which is rich in vitamins, natural carbohydrate, protein, tannins, gums and other antioxidants including minerals [1,2]. Hibiscus Sabdariffa plant has so many applications industrially and medically. Industrially, it can be used as spices for soup, sauces, wine and juice [3], infusion (herbal tea) [4], and dyes [5]. Medically, it can be used for curing allergies, high blood pressure [6], diabetes mellitus [7], for the stimulation of intestinal peristalsis [6] and for the reduction of serum cholesterol in humans [8].

In rural areas, the calyces Hibiscus sabdariffa can be used to improve the economic value by using it as acid-base indicator in Chemistry Laboratory in Secondary Schools. This is as a result of the presence of anthocyanin compounds in rosella flowers.

Several studies have been reported by many investigators on the effectiveness of the indicator prepared from the calyces Hibiscus sabdariffa for acid-base titration. The indicator changes colour over a range of hydrogen ion concentration which is expressed as the $\mathrm{pH}$ ranges of blue, red and colourless [9]. A study has been carried out to compare the properties of acid-base indicator of Rose, Allamanda and Hibiscus flowers [10]. Similarly, the acid-base indicator properties of dyes from Basella alba and Hibiscus sabdariffa has been determined [11]. Rosella flower has been used as alternative indicators of Blue and Red litmus $[12,13]$. Natural acid indicator has been isolated from the flower sap of Rosella $[14,15]$.

Anthocyanin has been extracted from the corolla of Roselle and used as acid-base indicator. In the study, the properties of Hibiscus rosella indicator

*Address for Correspondence: Okonkwo Samuel Nonso, Department of Polymer and Textile Engineering, Federal University of Technology Owerri, Imo State, Nigeria, Tel: 07063866455; E-mail: samdamian10@gmail.com

Copyright: @ 2020 Onuegbu G, et al. This is an open-access article distributed under the terms of the Creative Commons Attribution License, which permits unrestricted use, distribution, and reproduction in any medium, provided the original author and source are credited.

Received 15 June 2020; Accepted 30 June 2020; Published 07 July 2020 with phenolphthalein and methyl orange indicators were compared. The performance of the natural indicator was found to be similar to that of methyl orange as the results showed that the Roselle's corolla indicator gave red colour in acidic solution and green in basic solution [16]. In another study, it was found that a solution of Hibiscus sabdariffa crude anthocyanidins can be employed as the end-point indicator in complexometric and weak acid-weak base titrations because the end results were identical to those reproduced with standard end-point indicators, erichrome black T and phenolphthalein [17].

The objective of this research was to extract the dye (acid-base indicator) from calyces Hibiscus sabdariffa and to determine the acid-base indicator properties of the dye extracted from the calyces Hibiscus sabdariffa, for the determination of the molar concentration (standardization) of the acid and the mass concentration of the acid.

\section{Materials and Methods}

\section{Collection of plant Materials}

The calyces Hibiscus sabdariffa was purchased at Ekeonunwa Market, Owerri, Imo State, Nigeria, in the month of October, 2019.

\section{Reagents and Apparatus}

The reagents used were Oxalic acid $\left(\mathrm{H}_{2} \mathrm{C}_{2} \mathrm{O}_{4}\right)$, Sodium hydroxide $(\mathrm{NaOH})$, Sodium carbonate $\left(\mathrm{Na}_{2} \mathrm{CO}_{3}\right)$, Disodium borate $\left(\mathrm{B}_{4} \mathrm{Na}_{2} \mathrm{O}_{7}\right)$, Hydrochloric acid $(\mathrm{HCl})$ and they were obtained from Mr Nti's laboratory, a Technologist in School of Agriculture and Agricultural Technology, Federal University of Technology Owerri, Nigeria. The reagents were of analytical standard.

The apparatus used were burette, conical flask, volumetric flask, beaker, funnel, automatic pipette, dropper, distillation apparatus, auto digital $\mathrm{pH}$ meter, heating mantle, oven, laboratory meter, electronic weighing balance, retort stand with clamp, wash bottle, spatula, stirrer, soxhlet extractor, desiccators, mechanical blender.

\section{Preparation and Extraction of the Indicator from the calyces Hibiscus Sabdariffa}

The flowers were washed with distilled water, dried in hot air oven at $40^{\circ} \mathrm{C}$ and ground into powder with mechanical blender. About $1.5 \mathrm{~kg}$ of the calyces Hibiscus sabdariffa was weighed and treated with two litres of ethanol at $70^{\circ} \mathrm{C}$ in a Soxhlet extractor for $72 \mathrm{hrs}$. The extract was filtered and concentrated in vacuum and finally dried in a desiccator to remove residual 
water which yielded $200 \mathrm{~g}$ of the crude extract.

For the hot extract, $40 \mathrm{~g}$ of the powder was weighed using an electronic weighing machine. This was dissolved in $80 \mathrm{ml}$ of ethanol which boiled for 30 mins. It was extracted and filtered to obtain the dye solution which was concentrated to produce acid-base indicator.

For the cold extraction, the ground calyces Hibiscus sabdariffa was dissolved in $60 \mathrm{ml}$ of cold ethanol and left overnight, the solution was later extracted, filtered and concentrated by heating to produce an indicator for acid-base titration (Table $1 \&$ 2).

The calyces Hibiscus sabdariffa extract was respectively added to 0.03 $M$ of the bases which brought about the changes in colour of the mixture (end point). At these end points, the volumes of the acids used were recorded.

\section{Standardization of the Acid used}

The mean volumes of the acids were used to determine the molar concentration and mass concentration of all the acids used in this research work. Equation 1 was used in the determination of the molar concentration

$\frac{C_{A} V_{A}}{C_{B} V_{B}}=\frac{n_{a}}{n_{b}}$ Equation 1

where;

$\mathrm{C}_{\mathrm{A}}=$ Concentration of Acid

$\mathrm{C}_{\mathrm{B}}=$ Concentration of Base

$\mathrm{V}_{\mathrm{A}}=$ Volume of Acids,

$\mathrm{V}_{\mathrm{B}}=$ Volume of Base

$\mathrm{n}_{\mathrm{a}}=$ number of moles of acid

$\mathrm{n}_{\mathrm{b}}=$ number of moles of bases.

Mass Concentration $=$ Molar Concentration $\times$ Molar mass

\section{Results and Discussion}

The mean volume of all the acids used in the experiments was shown in Table 3-10. The indicators, colour changes, molar and mass concentration of the acids used are shown in the below following tables.

Table 1. Titration of Acid/Base with the $\mathrm{pH}$.

\begin{tabular}{lcc}
\hline \multicolumn{1}{c}{ Titration } & Acid $/ \mathrm{Base}$ & Rapid change of $\mathbf{p H}$ \\
\hline Strong acid/Strong base & $\mathrm{HCl} / \mathrm{NaOH}$ & 3.4 to 6.4 \\
\hline Strong acid/Weak base & $\mathrm{HCl} / \mathrm{Na}_{2} \mathrm{CO}_{3}$ & 3.4 to 5.2 \\
\hline Strong acid/Weak base & $\mathrm{HCl} / \mathrm{B}_{4} \mathrm{Na}_{2} \mathrm{O}_{7}$ & 3.4 to 4.5 \\
\hline Weak acid/Strong base & $\mathrm{H}_{2} \mathrm{C}_{2} \mathrm{O}_{4} / \mathrm{NaOH}$ & 3.4 to 9.0 \\
\hline Weak acid/Weak base & $\mathrm{H}_{2} \mathrm{C}_{2} \mathrm{O}_{4} / \mathrm{Na}_{2} \mathrm{CO}_{3}$ & 3.4 to 3.82 \\
\hline Weak acid/Weak base & $\mathrm{H}_{2} \mathrm{C}_{2} \mathrm{O}_{4} / \mathrm{B}_{4} \mathrm{Na}_{2} \mathrm{O}_{7}$ & 3.4 to 3.7 \\
\hline
\end{tabular}

Table 2. Colour Changes of the calyces Hibiscus sabdariffa.

\begin{tabular}{cccc}
\hline Dye stuff & Colour of the dye & Basic & Acids \\
\hline Hibiscus sabdariffa & Wine & Green & Red \\
\hline
\end{tabular}

Table 3. Titration of $\mathrm{HCl} / \mathrm{NaOH}$ Using Hot Ethanol Extract of Hibiscus sabdariffa.

\begin{tabular}{cccc}
\hline Burette reading & $\begin{array}{c}\text { First reading } \\
\left(\mathbf{c m}^{3}\right)\end{array}$ & $\begin{array}{c}\text { Second reading } \\
\left(\mathbf{c m}^{3}\right)\end{array}$ & $\begin{array}{c}\text { Third reading } \\
\left(\mathbf{c m}^{3}\right)\end{array}$ \\
\hline Final reading & 18.50 & 36.90 & 18.40 \\
\hline Initial reading & 0.00 & 18.50 & 0.00 \\
\hline $\begin{array}{c}\text { Volume of acid } \\
\text { used }\end{array}$ & 18.50 & 18.40 & 18.40 \\
\hline
\end{tabular}

From Table 3, the mean titre value is calculated using the Equation 2 as follows:

Mean titre value $=\frac{V_{A 1}+V_{A 2}+V_{A 3}}{3} \ldots \ldots \ldots \ldots \ldots \ldots$ Equation 2 where;

$\mathrm{V}_{\mathrm{A} 1}=$ Volume of acid used in first reading

$\mathrm{V}_{\mathrm{A} 2}=$ Volume of acid used in second reading

$\mathrm{V}_{\mathrm{A} 3}=$ Volume of acid used in third reading

$$
\begin{aligned}
& \text { Mean titre value }=\frac{18.50+18.40+18.40}{3} \\
& =18.43 \mathrm{~cm}^{3} \\
& =0.0184 \mathrm{dm}^{3}
\end{aligned}
$$

From Table 4, the mean titre value was calculated using Equation 2: Table 4. Titration of $\mathrm{HCl} / \mathrm{NaOH}$ using cold ethanol extract of Hibiscus sabdariffa.

\begin{tabular}{cccc}
\hline Burette reading & $\begin{array}{c}\text { First reading } \\
\left(\mathbf{c m}^{3}\right)\end{array}$ & $\begin{array}{c}\text { Second reading } \\
\left(\mathbf{c m}^{3}\right)\end{array}$ & $\begin{array}{c}\text { Third reading } \\
\left(\mathbf{c m}^{\mathbf{3}} \mathbf{)}\right.\end{array}$ \\
\hline Final reading & 18.80 & 37.60 & 18.80 \\
\hline Initial reading & 0.00 & 18.80 & 0.00 \\
\hline $\begin{array}{c}\text { Volume of acid } \\
\text { used }\end{array}$ & 18.80 & 18.80 & 18.80 \\
\hline
\end{tabular}

$$
\begin{aligned}
& \text { Mean titre value }=\frac{18.80+18.80+18.80}{3} \\
& =18.80 \mathrm{~cm}^{3} \\
& =0.0188 \mathrm{dm}^{3}
\end{aligned}
$$

\begin{tabular}{|c|c|c|c|}
\hline Burette reading & $\begin{array}{l}\text { First reading } \\
\qquad\left(\mathrm{cm}^{3}\right)\end{array}$ & $\begin{array}{l}\text { Second reading } \\
\left(\mathrm{cm}^{3}\right)\end{array}$ & $\begin{array}{l}\text { Third reading } \\
\qquad\left(\mathrm{cm}^{3}\right)\end{array}$ \\
\hline Final reading & 20.30 & 40.70 & 20.40 \\
\hline Initial reading & 0.00 & 20.30 & 0.00 \\
\hline $\begin{array}{c}\text { Volume of acid } \\
\text { used }\end{array}$ & 20.30 & 20.40 & 20.40 \\
\hline \multicolumn{4}{|c|}{$\begin{array}{l}\text { Mean titre value }=-1 \\
=20.37 \mathrm{~cm}^{3}\end{array}$} \\
\hline
\end{tabular}

From Table 5, the mean titre value was calculated using Equation 2:

Table 5. Titration of $\mathrm{H}_{2} \mathrm{C}_{2} \mathrm{O}_{4} / \mathrm{NaOH}$ using hot ethanol extract of Hibiscus sabdariffa.

From Table 6, the mean titre value was calculated using Equation 2:

Table 6. Titration of $\mathrm{H}_{2} \mathrm{C}_{2} \mathrm{O}_{4} / \mathrm{NaOH}$ using cold ethanol extract of Hibiscus sabdariffa.

\begin{tabular}{cccc}
\hline Burette reading & $\begin{array}{c}\text { First reading } \\
\left(\mathbf{c m}^{3}\right)\end{array}$ & $\begin{array}{c}\text { Second reading } \\
\left(\mathbf{c m}^{3}\right)\end{array}$ & $\begin{array}{c}\text { Third reading } \\
\left(\mathbf{c m}^{3}\right)\end{array}$ \\
\hline Final reading & 20.50 & 41.00 & 20.50 \\
\hline Initial reading & 0.00 & 20.50 & 0.00 \\
\hline $\begin{array}{c}\text { Volume of acid } \\
\text { used }\end{array}$ & 20.50 & 20.50 & 20.50 \\
\hline
\end{tabular}

$$
\begin{aligned}
& \text { Mean titre value }=\frac{20.50+20.50+20.50}{3} \\
& =20.50 \mathrm{~cm}^{3} \\
& =0.0205 \mathrm{dm}^{3}
\end{aligned}
$$

From Table 7, the mean titre value was calculated using Equation 2:

$$
\begin{aligned}
& \text { Mean titre value }=\frac{19.70+19.90+19.60}{3} \\
& =19.73 \mathrm{~cm}^{3} \\
& =0.0197 \mathrm{dm}^{3}
\end{aligned}
$$


Table 7. Titration of $\mathrm{H}_{2} \mathrm{C}_{2} \mathrm{O}_{4} / \mathrm{NaOH}$ using hot ethanol extract of Hibiscus sabdariffa.

\begin{tabular}{cccc} 
Burette reading & First reading $\left(\mathbf{c m}^{3}\right)$ & Second reading $\left(\mathbf{c m}^{3}\right)$ & Third reading $\left(\mathbf{c m}^{3}\right)$ \\
\hline Final reading & 19.70 & 39.60 & 19.60 \\
\hline Initial reading & 0.00 & 19.70 & 0.00 \\
Volume of acid used & 19.70 & 19.90 & 19.60
\end{tabular}

Table 8. Titration of $\mathrm{HCl} / \mathrm{B}_{4} \mathrm{Na}_{2} \mathrm{O}_{7}$ using cold ethanol extract of Hibiscus sabdariffa.

\begin{tabular}{cccc}
\hline Burette reading & First reading $\left(\mathbf{c m}^{3}\right)$ & Second reading $\mathbf{( \mathbf { c m } ^ { 3 } )}$ & Third reading $\left(\mathbf{c m}^{\mathbf{3}}\right)$ \\
\hline Final reading & 19.60 & 39.10 & 19.50 \\
\hline Initial reading & 0.00 & 19.60 & 0.00 \\
\hline Volume of acid used & 19.60 & 19.50 & 19.50 \\
\hline
\end{tabular}

Table 9. Titration of $\mathrm{HCl} / \mathrm{Na}_{2} \mathrm{CO}_{3}$ using hot ethanol extract of Hibiscus sabdariffa.

\begin{tabular}{cccc}
\hline Burette reading & First reading $\left(\mathbf{c m}^{3}\right)$ & Second reading $\left(\mathbf{c m}^{3}\right)$ & Third reading $\left(\mathbf{c m}^{3}\right)$ \\
\hline Final reading & 20.00 & 40.00 & 20.20 \\
\hline Initial reading & 0.00 & 20.00 & 0.00 \\
\hline Volume of acid used & 20.00 & 20.00 & 20.20
\end{tabular}

Table 10. Titration of $\mathrm{HCl} / \mathrm{Na}_{2} \mathrm{CO}_{3}$ using cold ethanol extract of Hibiscus sabdariffa.

\begin{tabular}{cccc}
\hline Burette reading & First reading $\left(\mathbf{c m}^{3}\right)$ & Second reading $\left(\mathbf{c m}^{3}\right)$ & Third reading $\left(\mathbf{c m}^{3}\right)$ \\
\hline Final reading & 20.100 & 40.300 & 20.100 \\
\hline Initial reading & 0.00 & 20.10 & 0.00 \\
Volume of acid used & 20.10 & 20.20 & 20.10 \\
\hline
\end{tabular}

Table 11. Determination of Molar and Mass Concentrations.

\begin{tabular}{|c|c|c|c|c|c|c|c|c|c|}
\hline $\begin{array}{c}\text { Acid/0.03 M } \\
\text { of Bases }\end{array}$ & Indicator & $\begin{array}{l}\text { End-point/Colour } \\
\text { change }\end{array}$ & $\begin{array}{c}\text { Molar } \\
\text { Concentration } \\
\left(\mathrm{mol}^{\prime} / \mathrm{dm}^{3}\right)\end{array}$ & $\begin{array}{c}\text { Volume } \\
\text { of Base, } \\
V_{B}\end{array}$ & $\begin{array}{l}\text { Volume } \\
\text { of Acid, } \\
V_{A}\end{array}$ & $\begin{array}{l}\text { Number } \\
\text { of moles } \\
\text { of Acid, } n_{A}\end{array}$ & $\begin{array}{c}\text { Number of } \\
\text { moles of } \\
\text { Base, } n_{B}\end{array}$ & $\begin{array}{c}\text { Molar } \\
\text { Concentration } \\
\left(\mathrm{mol}^{2} \mathrm{dm}^{3}\right) \mathrm{C}_{\mathrm{A}}\end{array}$ & $\begin{array}{c}\text { Mass } \\
\text { Concentration } \\
\left(\mathbf{g} / \mathrm{dm}^{3}\right)\end{array}$ \\
\hline \multirow[t]{2}{*}{$\mathrm{HCl} / \mathrm{NaOH}$} & $\begin{array}{l}\text { Hot Ethanol } \\
\text { Extract }\end{array}$ & $\begin{array}{l}\text { Wine to greenish } \\
\text { yellow }\end{array}$ & 0.03 & 0.02 & 0.0184 & 1 & 1 & 0.0326 & 1.1899 \\
\hline & $\begin{array}{l}\text { Cold Ethanol } \\
\text { Extract }\end{array}$ & Red to light green & 0.03 & 0.02 & 0.0188 & 1 & 1 & 0.0319 & 1.1644 \\
\hline \multirow[t]{2}{*}{$\mathrm{H}_{2} \mathrm{C}_{2} \mathrm{O}_{4} / \mathrm{NaOH}$} & $\begin{array}{l}\text { Hot Ethanol } \\
\text { Extract }\end{array}$ & Wine to colourless & 0.03 & 0.02 & 0.0204 & 1 & 2 & 0.0147 & 1.3230 \\
\hline & $\begin{array}{l}\text { Cold Ethanol } \\
\text { Extract }\end{array}$ & Red to colourless & 0.03 & 0.02 & 0.0205 & 1 & 2 & 0.0146 & 1.3140 \\
\hline \multirow[t]{2}{*}{$\mathrm{HCl} / \mathrm{B}_{4} \mathrm{Na}_{2} \mathrm{O}_{7}$} & $\begin{array}{l}\text { Hot Ethanol } \\
\text { Extract }\end{array}$ & Wine to pink & 0.03 & 0.02 & 0.0197 & 2 & 1 & 0.0609 & 4.4457 \\
\hline & $\begin{array}{l}\text { Cold Ethanol } \\
\text { Extract }\end{array}$ & $\begin{array}{l}\text { Light pink to } \\
\text { colourless }\end{array}$ & 0.03 & 0.02 & 0.0195 & 2 & 1 & 0.0615 & 4.4895 \\
\hline \multirow[t]{2}{*}{$\mathrm{HCl} / \mathrm{Na}_{2} \mathrm{CO}_{3}$} & $\begin{array}{l}\text { Hot Ethanol } \\
\text { Extract }\end{array}$ & Green to light green & 0.03 & 0.02 & 0.0200 & 2 & 1 & 0.0600 & 4.3800 \\
\hline & $\begin{array}{l}\text { Cold Ethanol } \\
\text { Extract }\end{array}$ & Green to brown & 0.03 & 0.02 & 0.0201 & 2 & 1 & 0.0597 & 4.3581 \\
\hline
\end{tabular}

From Table 8, the mean titre value was calculated using Equation 2:

Mean titre value $=\frac{19.60+19.50+19.50}{3}$

$=19.53 \mathrm{~cm}^{3}$

$=0.0195 \mathrm{dm}^{3}$

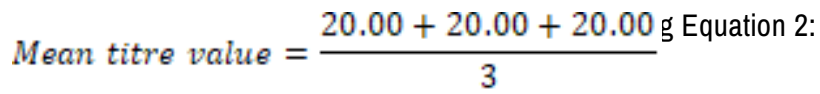

$=20.00 \mathrm{~cm}^{3}$

$=0.0200 \mathrm{dm}^{3}$

From Table 10, the mean titre value was calculated using Equation 2:

$$
\begin{aligned}
& \text { Mean titre value }=\frac{20.10+20.20+20.10}{3} \\
& =20.13 \mathrm{~cm}^{3} \\
& =0.0201 \mathrm{dm}^{3}
\end{aligned}
$$

From the tables above, there was appearance of the sharp end point in the titrimetric analysis, these could be as a result of the presence of flavonoids and is in agreement with [10]. Between the two methods of extraction used, hot extraction yielded better because more dye was extracted having a wine colour. From the preliminary test carried out, Hibiscus sabdariffa extract displayed red colour in acid and green in alkaline. The colours were also observed in [11]. The mean values of the volume of acids used in the work were calculated, used in the standardization of acids and determination of mass concentration of the acids. 


\section{Conclusions}

The use of Hibiscus sabdariffa as indicator in acid-base titration cannot be over emphasized in acid-base titration. The ethanol extract showed wine colour in acid solution, green in basic solution and it was employed for the standardization of all the acids used and for the determination of the mass concentration.

\section{References}

1. Adegunloye BJ, Omoniyi Owolabi, Ajabonna OP. "Mechanism of Blood Pressure Lowering Effects of the Calyx Extract of Hibiscus sabdariffa in Rats." Journal of Science (1996): 235-238.

2. Ahmed, Fatima Abdallah Mohammed, Nuha Mohammed Elhasan Satti, and Sharaf Eldin Hussain Eltahir. "A comparative study on some major constituents of karkade (Hibiscus sabdariffa L.-roselle plant)." International Journal of Life science and Pharma Research 9 (2019): 1-12.

3. Yadong Q, Kit LC, Fatemah M, Mila B, et al. (2005). Biological Characteristics, Nutritional and Medicinal Value of Roselle, Hibiscus sabdariffa. Circular-Urban Forestry Natural Resources and Environment, No 604. www.suagcentre.com.

4. Obidoa Onyechi, Parker Elijah Joshua, John Egemole, and Ikeyi Adachukwu. "Phyochemical Analysis of Aqueous Flower Extract of Hibiscus sadariffa (Zobo Flower)." Research Journal of Pharmacognosy and Phytochemistry 3 (2011): 169-173.

5. Abubakar S, Usman Etim, Nnadi, and Alaku. "Application of organic dyes from roselle calyx (Hibiscus sabdariffa Linn) for mycological staining." Indian J Innovations Dev 1 (2012): 687-690.

6. Perry "Medical plants of East and South East Asia." MIT Press, Cambridge (1980): 312-322.

7. Rosemary, Rosidah, and Ginda Haro. "Antidiabetic effect of roselle calyces extract (Hibiscus sabdariffa L.) in streptozotocin induced mice." Int J PharmTech Research 6 (2014): 1703-1711.

8. Lin Tzu-Li, Hui-Hsuan Lin, Chang-Che Chen, Ming-Cheng Lin, et al. "Hibiscus sabdariffa extract reduces serum cholesterol in men and women." Nutrition research 27 (2007): 140-145.
9. Pimpodkar Surve, and Bhise. "Use of Bixa orellana fruit extract as a natural indicator in acid base titration." Int J Pharm Res Sch 3 (2014): 156-159.

10. Okoduwa, Stanley IR, Lovina O Mbora, Matthew E Adu, et al. "Comparative analysis of the properties of acid-base indicator of Rose (Rosa setigera), Allamanda (Allamanda cathartica), and Hibiscus (Hibiscus rosa-sinensis) flowers." Biochemistry research international (2015).

11. Izonfuo, Fekarurhobo, Obomanu, and Daworiye. "Acid-base indicator properties of dyes from local plants I: dyes from Basella alba (Indian spinach) and Hibiscus sabdariffa (Zobo)." Journal of Applied Sciences and Environmental Management 10 (2006): 5-8.

12. Nuryanti Siti and Dwi Juli Puspitasari. "Rosella (Hibiscus sabdariffa) Flowers as Alternative Indicators of Blue and Red Litmus." Oriental Journal of Chemistry 35 (2019): 476-480.

13. Siti N. "Paper Indicator of Wora-wari Flower (Hibiscus rosa-sinensis L)." Proceeding of $3^{\text {rd }}$ International Conference on Research, Implementation and Education of Mathematics and Science (2016): 95-98.

14. Ekandem JE, and Owor AU. "Local flower extracts as simple acid-base indicators." J Chem Soc Nig 22 (1997): 98-103.

15. Poonam Gupta, Jain Pushpa, and Jain PK. "Isolation of natural acid base indicator from the flower sap of Hibiscus rosa sinensis." Journal of Chemical and Pharmaceutical Research 4 (2012): 4957-4960.

16. Nuryanti Siti, Sabirin Matsjeh, Chairil Anwar, Tri Joko Raharjo, et al. "Corolla of roselle (Hibiscus sabdariffa L.) as acid-base indicator." European journal of chemistry 4 (2013): 20-24.

17. Okonkwo and Tochukwu Josiah Nnaemeka. "Hibiscus sabdariffa anthocyanins: a potential two-colour end-point indicator in acid-base and complexometric titrations." Int J Pharm Sci Rev Res 4 (2010): 123-8.

How to cite this article: Onuegbu Genevieve, Nnorom Onyekachi, Okonkwo Samuel Nonso and Ojiaku Pascal. Acid-Base Indicator Properties of Dye from Local Plant: The Rosella Calyces (Hibiscus Sabdariffa). J Textile Sci Eng 10 (2020) doi: 10.37421/jtese.2020.10.409 